\title{
EFFECT OF HR DIVERSITY MANAGEMENT PRACTICES ON EMPLOYEE KNOWLEDGE SHARING: EXAMINING THE MEDIATING ROLE OF TRUST ON LEADERSHIP AND MODERATING ROLE OF COOPERATIVE NORMS
}

\author{
Irfan Raza ${ }^{1}$ \\ Department of Computer Science, \\ National University of Modern Languages-NUML, Islamabad, \\ Pakistan \\ Fouzia Tariq ${ }^{2}$ \\ Shaheed Zulfikar Ali Bhutto Institute of Science and Technology, \\ Islamabad, Pakistan
}

\begin{abstract}
Purpose: This study was aimed at exploring the effect of HR diversity management practices on employees' knowledge sharing with mediating role of trust on leadership and moderating role of cooperative norms.

Methodology: Quantitative-method research design was conducted in the study and data was collected from 4 large organizations of Pakistan for analysis. Convenient sampling technique was applied and sample size for the study was 256. Thirty six Likert-type questions were used to collect responses with á $=0.853$. Findings: The results demonstrate that HR diversity management has a significant positive effect on employee knowledge sharing. The trust on leadership has a mediating role between HR diversity management and knowledge sharing. Findings also show that cooperative norms have a moderating role between HR diversity management and knowledge sharing; cooperative norms also moderate the relationship of trust on leadership and employee knowledge sharing. Practical Implications: There are significant academic and practical implications which are briefly described in last part of the study.
\end{abstract}

Key Words: HR Diversity Management, Trust on Leadership, Cooperative Norms, Knowledge Sharing. \footnotetext{
and the management of the Institute of Business \& Technology (IBT)

1 Irfan Raza

:iraza@numl.edu.pk

2 Fouzia Tariq $\quad$ : fouzia.tariq@nadra.gov.pk

(C) IBT-JBS is published by the Institute of Business and Technology (IBT).

Main Ibrahim Hydri Road, Korangi Creek, Karachi-75190, Pakistan.
}

* The material presented by the author does not necessarily portray the viewpoint of the editors 


\section{INTRODUCTION}

Diversity management is significant nowadays. Carrell et al. (2006) explain workforce diversity as people differ in terms of age, gender, race, education, religion; culture and this difference affect their tasks and relationship while working in an organization. The reason behind this is that as social interaction and communication increased, global boundaries are reduced and international firms step up in different countries. Consequently, the business competition became more vigorous and local firms adopt international HR practices, and the company leaders search for less expensive and competitive workforce which can reduce cost and provide maximum productivity. All this leads to an increase in local and international diversified work force (Marques, 2008).

As various organizations flourish, diversity becomes the main factor of success for organizations (Waiganjo, Mukulu \& Kahiri, 2012). Currently, organizations' workforce consists of variety of people who are different in terms of behavior knowledge sharing, values and attitudes (D-Amato \& Zijlstra, 2008). Complex integration of diversity on workplace has now become alarming for HRM (Datta et al., 2005). Practitioners and researchers argue that diversity of workforce is double edged sword which has both advantages and disadvantages (Shen et al., 2009). Disadvantages are described as increased conflict, increase in training cost, high turnover, low productivity, less trust and breakdown of communication (D'Netto \& Sohal, 1999) whereas advantages are trust in organization and leadership, better quality solutions, excellent increase in productivity and a supportive behavior (Wilson \& Iles, 1999). Minimizing the disadvantages and maximizing the effective use of advantages is labeled as the diversity management (Beauregard \& Paquette, 2008). HRM has an important role for managing the diversity issues such as, HRM and diversity management both has to deal with people (Shen et al., 2009); the other thing which describes the link of HRM and diversity management is that HRM and diversity management has a direct relation with each other such as, workforce diversity affects the HRM policies and practices of the organization. For achieving ultimate motives from multifarious workforce an effective HRM is essential because it can give equality and inclusiveness (Datta et al., 2005). Shen et al. (2009) raise a point that practitioners and researchers focused more on equal employment opportunity (EEO) and affirmative actions (AA), but they do not much emphasize on utilization and valuing variety.

Different steps are taken for shifting economic trends, but very few studies are conducted in Pakistan for understanding the impact of HR diversity management practices on employee knowledge sharing. Shen et al. (2014) suggest that there is a need to conduct research on how HR diversity management practices are effecting on employee knowledge sharing behavior. In Pakistan, researchers argue that HR practices are hukou-based (original from china, rural migrated to urban after 1949 reform) (Chan $\& \mathrm{Li}, 1999$ ). Pakistani system is same as Hukou-based because the context is somewhat same. In other countries where people are discriminated not only on the bases of backgrounds, race, gender and age but on bases of hukou as well (Shen et al., 2014). In Pakistan, like China, people are migrated from rural to urban areas in search of jobs and occupations but they are being discriminated on the bases of wage, training, 
promotion, welfare and social insurance, so HR diversity management in Pakistan need to comprehend the inequality between rural and urban workforce. This study will also explore this context of diversity management. Study mainly focuses to examine the effect of HR diversity management practices on employee knowledge sharing behavior with moderating and mediating variables which are trust on leadership and cooperative norms. This study will contribute to HR diversity management practices literature in Pakistani context.

\subsection{Significance of the Study}

The study will help to understand how HR diversity management practices (equal employment opportunity, equality in training and development, reward promotion, performance assessment etc.) will be helpful to reshape individual behavior and perception about knowledge sharing. It will also be helpful for organizations to encourage and develop a learning environment where people are willing to share their knowledge and they have a trust on their leadership, which will ultimately facilitate organizations in increasing their productivity and performance.

\subsection{Aim and Objectives of Study}

The study aims at identifying the essential attributes of HR diversity management practices that may enable the organizations to enhance the individual knowledge sharing behavior.

The objectives of current study are:

$\S$ To determine the effect of HR diversity management practices on employee knowledge sharing behavior.

$\S$ To measure the mediating role of trust on leadership between HR diversity management and employee knowledge sharing

$\S$ To analyze the moderating role of cooperative norms between HR diversity management relationship and employee knowledge sharing. $\S$ To investigate the moderating role of cooperative norms between trust on leadership and employee knowledge sharing.

\section{LITERATURE REVIEW}

\subsection{Gap Identification}

Gap was identified from the previous literature of HR diversity management practices. The HR diversity management is an emerging concept. Few studies are available on this particular area. HR Diversity Management is unique thing but in Pakistan, it is still in its emerging stage. Shen et al. (2014) suggest that HR diversity management practices have great link with different behaviors within the organization and there is a need to conduct research which explores the impact of HR diversity management practices on leadership team work etc. This study is particularly based on 
that future direction which has been mentioned by Shen et al. (2014) study.

\subsection{HR Workforce Diversity Management Practices}

HR diversity management is concerned with workplace equality, valuing and making use of a diverse workforce (Shen et al., 2009; D'Netto \& Sohal, 1999). Human Resource Management is consisting on the activities and functions which maintain to attract, retain and develop the people within the organization (Lado \& Wilson, 1994). Human Resource Management mainly consists of personnel recruitment, training and development, performance review and reward (Shen et al., 2009). All these practices mainly focus on people's management because ultimately all have to do with humans who are diverse and different from each other. Best results from HR Management practices could achieve from better management of diversity because it affects individual and organization as a whole (Kossek et al., 2005). The Role of HR is very important in diversity management practices. Few decades before diversity management was considered as an equal employment opportunity and affirmative action, but now focus has been changed on diversity management (Kossek et al., 2005; Pitts \& Jarry, 2009). Shen et al. (2009) proposed two prospects of diversity; one is compliance with AA and EEO laws and the second one is using workforce valuing. Organization effectiveness can be increased by increasing workforce diversity and making best use of that diverse workforce. So it can be said that HR diversity management does not only minimize the negative effect but it also helps to achieve organizational outcomes by using that workforce effectively. That diverse and competitive workforce can be achieved if firms give employment opportunity to those who are not in main stream and living in rural areas (Reskin \& McBrier, 2000). When an organization recruits that workforce and brings it into limelight by giving them training and empowering them for decision making, their attitude will be more helpful and learning oriented which will ultimately lead organization to achieve its outcome (Kossek et al., 2005; Ryne \& Rosen, 1995; Roberson et al., 2003). All HR practices like recruitment, training, promotion, reward and performance management should focus on that workforce which is not in limelight but can be helpful for organization to get a competitive edge. All HR management practices should ensure that an organization is compiling not only EEO laws but also valuing in-depth diversity by developing them effectively (Kossek et al., 2005). Promotion, reward and PM system should be clearly focused on managing diversity issues (Allen et al., 2003).

\subsection{Knowledge Sharing}

Knowledge sharing is a human behavior which can be explained as when individual is willing to share and transfer his/her knowledge to other members. This will lead organization towards improvement of performance and innovation for getting competitive edge organizational performance (Ipe, 2003). If in any organization, individuals are not willing to share knowledge and they want to keep that knowledge with them then that organization cannot achieve its ultimate outcomes, because when knowledge sharing occurs within any organization then people provide job related knowledge and support to their colleagues and people within the organization (Anand et al., 2010). Knowledge 
sharing is that attitude in which people are willing to expose their intellectual knowledge and share their intellectual skills to other member but researchers argue that willingness doesn't mean that he /she will actually share their knowledge. Actual knowledge sharing is influenced by many other factors (Alavi \& Leidner, 2001). Researchers suggested that knowledge sharing environment can be promoted by changing individual attitude and behavior rather that by directly measuring or training to implementing from their business strategy. Those organizations which tried to achieve knowledge sharing results directly from business strategy are not successful rather than those which try to achieve it by focusing on behavior of an individual (Bock \& Kim, 2002). So it is necessary that organization should take initiatives to overcome an employee fears and by focusing on their behavior change for maintaining and developing a positive environment for actual knowledge sharing results (Robinson et al., 2005). Because without knowledge sharing a single person will own knowledge about particular things this will lead organization an environment where few individual poses knowledge and rest of the people are not aware about it. Equity theory suggests that people working in an organization always try to maintain a balance between what they are bringing into a job which is input and what they are getting as an output from that job, that also refers as social comparison (Adams \& Lamont, 2003). The social comparison is a term which is used to define as "the people who feel and think that fair treatment is an important aspect" (Lin, 2008). Diversity Management practices plays an important role for developing an environment where people feel that they are being treated fairly and they feel satisfied. This positive attitude will ultimately lead towards an organization where people feel comfortable and share their views and ideas openly (Kochan, 2003).

\subsection{Trusts on Leadership}

There are different definitions of trust but the most common and easy to understand is that the people, on whom we are dependent, fulfill our expectations. It can be explained like this that party on whom one person is dependent will pose that behavior which meets all the expectations of a trusty (Martins, 2002). Trust is that when one person is fully confident that the other person will prove with his /her action that he/she has good intentions for him/her (Cook \& Wall, 1980). There are also numbers of definitions which describe about trust (Boon \& Miller, 1999). Trust is that point where people are willing to open up their self by ignoring that the other person can exploit their situation (Martins, 2002). Trust has different attributes. It is found between families and friends, communities and organizations, societies and in nations enlarge (Hardin, 2002). Workplace trust is a well-known phenomenon now a days. It is described as trust between coworker and manager, even trust on organization is also included in workplace trust terminology (Dirks \& Ferrin, 2002). Trust on leader is described as people willing to follow blindly and have faith that what so ever a leader is trying to achieve is in their best interest (Martins, 2002). Employee's trust on leadership means that employee has faith and believes that his/her manager/leader/supervisor will not do anything which is harmful for him/her. He/she has an ultimate believe that their leader will do those things which are maximum beneficial for them (Dirks \& Ferrin, 2002). Culture also plays an important role when there is a measurement of trust. In Asian culture people 
trust more on their family and close relations. There is low workplace trust culture in Asia (Hardin, 2002).

By focusing on HR diversity management practice and social exchange all employees feel and think that practices of diversity management show the organization equality and fairness to employees and if organization has strong HR diversity management practices they will feel more trustworthiness toward their leadership, so it could be concluded that HR diversity practices are directly linked with trust on leadership (Mayer et al., 1995). When employees trust their leadership there is an environment where people can develop their capabilities, also when their will be trust on leadership people will also start trusting their environment coworker, and organization as a whole. When there will be a great level of trust between leader and coworker in an organization that will ultimately lead organization where people are open and willing to share their knowledge. Then organization will ultimately achieve its objective and become a learning organization (Collins \& Smith, 2006). So it could be concluded that trust on leader is a vital role in creating and developing a fearless environment where people are willing to share their views ideas and knowledge openly (Shen et al., 2013). On the bases of literature it could be argued that Trust on leadership is an important role between HRDM and knowledge sharing.

\subsection{Cooperative Norms}

Knowledge sharing within an organization is generally referred as a behavior when a person is willing to share his/her cognitive knowledge with other members of an organization. According to social exchange theory when a person shares anything in terms of knowledge with coworkers he/she also wants to get back some kind of information from them as well. In other words if an employee shares a particular job related skill, he also wants to learn back some other skill from his/her fellows (Bock et al., 2005). Knowledge sharing is highly influenced by many factors among which one of the most important is cooperative norms (Mossholder et al., 2011). Group norms play a vital role in knowledge sharing because when there will be a group which has a norm to cooperate with other for accomplishment of a task and particular assignment. So when this type of a group is present within the organization, people will feel more confident to share their knowledge and job related information (Van Dyne, Cummings $\&$ McLean, 1995). Cooperative norm has been seen as a link with social exchange process in term of that when one person tries to help someone the feeling of obligation is emerged within individual and as a result he also tries to pose same behavior which ultimately leads towards desired knowledge sharing outcomes (George \& Jones, 1997). If there will be an environment where people feel obliged and try to return the favor back that environment is most beneficial for the organization. Theory of Reasoned Action by Fishbein \& Ajzen (1975) describes that people evaluate their actions in term of reaction they will receive in return of that action. In case of knowledge sharing same goes with people share their knowledge they evaluate that what they are getting in result. Expectation and evaluation are measured by the cooperative norms and trust on leader within the organization. Those organizations where group cooperative norms are high people feel more confident and fearless when they share their knowledge and 
those where there is low or no cooperative norms people are reluctant to pose trust worthy behavior (Ehrhart \& Naumann, 2004). When their will be norm of cooperation among teams and group, knowledge sharing would be seen as morality (Anderson \& Person, 1999). Cooperative norms will encourage the cooperation and develop a sense of synergy between the teams and groups as a result people started feeling enjoying their work and there is trust oriented learning environment is emerged (Forsyth, 1999). When there will be synergy and environment of trust and friendship within team members they will start treating coworker just like their family and also they start sacrificing their interest on their fellows (Anderson \& Person, 1999; Hillsdale et al., 2006). If there will be a group which is having low cooperative norms will not be enjoying their work and also they will not feel confident to share their knowledge. So knowledge sharing behavior is also affected by cooperative norms along with all other incidents which are HR diversity management and trust leadership. Cooperative norms also play an important role for creating the environment of real knowledge sharing (Huang, Davison \& Gu, 2008).

\subsection{Theoretical Frame Work \& Research Hypotheses}

Relationship among all the variables discussed in this study is presented in figure 1. HR diversity management is considered as predictor variable and its impact is checked on employee knowledge sharing which is predicted variable. Trust on leadership mediates the relation of predictor and predicted. Moreover, cooperative norms work as a moderator on HR diversity management and trust on leadership, and also on trust on leadership and employee knowledge sharing.

(See Figure in APPENDIX)

Based on the theoretical framework presented in figure 1, following research hypotheses are made.

H1: HR Diversity Management practices have positive impact on Employee Knowledge Sharing.

H2: Trust on Leadership mediates the relationship between HR Diversity Management and Employee Knowledge Sharing.

H3: Cooperative Norms moderate the relationship between Trust on Leadership and Employee Knowledge Sharing.

H4: Cooperative Norms moderate the relationship between HR Diversity Management and Trust on Leadership.

\section{RESEARCH METHODOLOGY}

\subsection{Research Design}


The nature of current study is descriptive and casual. The data was collected from four large organization of Islamabad Pakistan. HR diversity management practice are taken as independent variable and knowledge sharing is taken as dependent variable, Trust on leadership was taken as mediator between HRDM and Knowledge sharing, cooperative norms are taken as moderator between HRDM and KN and also between HRDM and Trust on leadership.

\subsection{Research Strategy}

To collect responses from respondents a questionnaire survey was be administered. Respondents were asked to give answers on a five point likert scale, with scale anchors ranging from 'strongly disagree' (1) to 'strongly agree' (5). Structured questionnaire was closed ended and splitted into two sections. First section gathered demographic information from respondents which included gender, age, position and education. There were two aspects of position namely managerial and non-managerial position. In second section respondents gave responses about the variables of this study. 13 questions were developed for HR diversity management, 12 questions for knowledge sharing, 6 for trust on leadership and 5 questions were developed for cooperative norms. To give feedback for section two respondents needed to check or tick the particular check boxes of likert scale items.

\subsection{Respondents}

Questionnaire were sent to different departments like production, marketing and finance for getting exact information about HR diversity management practices and their effect on employee knowledge sharing.

\subsection{Development of Measures}

\subsubsection{HR Diversity Management Practices}

HR diversity management practices (á $=0.89)$ was measured using 13 items scale adopted from (Shen et al., 2014). The included items were providing employment opportunities to rural migrant, equality, providing training and development, compensation and reward with discrimination on the bases of hukou or other characteristics.

\subsubsection{Knowledge Sharing}

Knowledge sharing (á = 0.84) scale was adopted from (Bock \& Kim, 2002). Scale consisted of 12 items which was divided into two dimensions. The first dimension is willingness intentions to share knowledge and the second is actual knowledge sharing behavior. First dimension has 5 items and second has 7 items.

\subsubsection{Trust on Leadership}

Trust on leadership (á $=0.83$ ) was measured by using six items adopted from 
(Podsak et al., 2003). Sample item was 'My leader will never try to deceive worker for gaining any advantage'.

\subsubsection{Cooperative Norms}

The items used to measure cooperative norms (á $=0.88$ ) were adopted from (Kreitz, 2009). The sample was 'There is harmony within the team'.

\subsection{Sample \& Sampling Technique}

A convenient sampling technique was used to gathered data. There is large amount of population which could cover under the scope of the study so among all convenient was the best suitable. Four large size organizations which are located in Islamabad were selected for survey study. Among them, one is government and other 3 are private organizations. Total 300 questionnaires were distributed but 256 were collected back. So over all response rate was $77 \%$.

\subsection{Statistical Tools}

Data analysis is planned to measure all components of gathered data with certain analytical and logic reasoning. It is an organized process that composes of investigating, transmuting and representing data to summarize and interpret the results for valuable conclusions (David, 2012). Statistical Package for Social Sciences (SPSS) version 20 and Microsoft Excel software tools were used to analyze and interpret data. To check reliability of test instrument Cronbach's Alpha test was applied on responses. Descriptive statistics was tested on demographic variables. Multiple regression and correlation analysis were applied to analyze the relationship between predictor and predicted variables. To test effect of mediating and moderating variables Barron \& Kenny (1986) method has been used for independent variable (HR diversity management), mediating variable (trust on leadership) and Moderating variable (cooperative norms) on Dependent variable (knowledge sharing).

\section{RESULTS}

This section of research study attempts to analyze, interpret and explain the meaning of the findings of the data collected. The main aim of this study is to measure and evaluate the impact of HR diversity management practices on employee knowledge sharing behavior. This study also analyzes the mediating role of trust in leadership and moderating role of cooperative norms on HR diversity management and employee knowledge sharing. This is a quantitative study so results can be expressed in form of ratios, percentages and tables to give meaningful information of responses collected from respondents.

\subsection{Demographics}

(See Table in APPENDIX) 
Demographic variable Age demonstrate that 57\% respondent were 18-29 year $37 \%$ were $30-393.5 \%$ were $40-49$ and $2.7 \%$ were 50 or above. Gender shows that $79 \%$ Respondents were male and only $21 \%$ were female. Education statistics shows that $7 \%$ respondents were having high school or diploma $37 \%$ were having Bachelor's degree, $43 \%$ were masters and $12.5 \%$ were post masters. Position were demographic were measures as 2 levels Managerial and Non managerial 60.9\%respondents were on managerial position and $39.1 \%$ were on non-managerial position.

\subsection{Reliability Analysis}

Reliability test are used to measure the reliability and internal consistency of item. Consistency of items is measured by alpha values.

\section{Table-2 Reliability Statistics}

\section{(See Table-2 in APPENDIX)}

Here the variable HRDM were measured by using 13 item and its Cronbach's á is 0.916 which is greater than $0.7, \mathrm{KNS}$ is measured by using 12 items and its Cronbach's á is 0.881 which is again greater than 0.7 , TOL is measured by using 6 items and its Cronbach's á is 0.816 greater than $0.7, \mathrm{CN}$ is measured by using 5 items and its Cronbach's á is 0.799 which is greater than 0.7.hense this demographic table explain that all items are consistent and reliable. There is significance difference has been found when sample 256 sample size is used.

\subsection{Descriptive Statistics}

\section{(See Table-3 in APPENDIX)}

Table-3 statics shows the minimum, maximum, mean and standard deviation of all variables values. Mean values show that average response of respondents is more likely toward agree (between 3-neutral to 4-agree), whereas standard deviation values are less than 1 which show that overall there is lesser variation in response level of all variables.

\subsection{Mean, Standard Deviation and Pearson's Correlation}

Table 4 is presenting the relationship among the variables, there is significant positive relationship exist between variables of this study. There is significant positive relation has been shown between HRDM and Knowledge sharing. The Positive interaction shows that if there will be a good HR diversity management practices exist in the organization employee will tend to show more knowledge sharing behavior. Trust on leadership also has a significant linear relation with Knowledge sharing hence if there will be trust on leadership exist in the organization people will tend to show more 
knowledge sharing intentions. There is also significant linear relationship exist between Cooperative Norms and Knowledge sharing, since high cooperative norms will show high knowledge sharing within the organization. Table -4 also shows that mean values for all the variables is showing that mostly respondent were responses were towards agree. Hence it shows that the organizations which are selected as population were presenting HRDM and also respondents have awareness about diversity trends.

(See Table-4 in APPENDIX)

\subsection{Regression Analysis for Testing Hypotheses}

After measuring the relation exists among all variables, the test of hypothesis has been conducted. For proving hypothesis-1 linear regression has been used whereas for testing hypothesis-2 Mediation Barron-Kenny (1986) has been used, also for testing hypothesis 3,4 Moderation Barron-Kenny (1986) has been used.

\subsubsection{Testing of Hypotheses- 1}

For checking the Effect of HRDM on knowledge sharing linear regression test has been conducted. Since table- 4 has shown that there is significant positive relation exists between the two variables it also means that one variable has significant effect on other variable (hypothesis-1)

(See Table-5 in APPENDIX) $<.05$

Note. $\mathrm{R}=0.737 ; \mathrm{R}^{2}=.543 ;$ Adjusted $\mathrm{R}^{2}=0.542 ; \mathrm{F}(1,254)=302.368, \mathrm{p}<0.05 ; * \mathrm{p}$

Table-5 describes that HR diversity management significantly affects knowledge sharing $B=0.765, t=17.389, p<0.05$. Standardized coefficient $\beta=0.737, p<0.05$ shows that hypothesis-1 is accepted.

\subsubsection{Testing of Hypothesis -2}

Table 6 presents the statistical results of mediation role of trust on leadership between HR diversity management and employee knowledge sharing.

(See Table-6 in APPENDIX)

Results reported in table-6 show that all assumptions of Barron and Kenny (1986) are proved. First Assumption is that there must present a significant association between independent variable and dependent variable (HRDM and knowledge sharing), as HRDM is significantly predicting KNS. The equation is (KNS) $0.765(0.044), t=$ $17.389, \beta=0.737, p=0.000$. The second assumption is that HRDM should significantly predict trust on leadership. Equation from table-6 is derived as, (HRDM) 0.684(0.052), 
significantly predict dependent variable so here for TOL and knowledge sharing the equation is, (TOL) 0.62(0.047), $\mathrm{t}=13.246, \beta=0.639, \mathrm{p}=0.000$. Step four of Barron and Kenny (1986) is conducted with help of simple regression. Results reported that trust on leadership is significantly predicting knowledge sharing and equation for this is $(\mathrm{HRDM}) 0.571(0.054), \mathrm{t}=10.57, \beta=0.551$. There is significant raise in adjusted $\mathrm{R}^{2}$ which increases from 0.542 to 0.591 . It can be explained as trust on leadership partially mediates the relationship of HRDM and Knowledge sharing.

\subsection{Testing of Hypothesis 3}

As all three assumptions of Barron and Kenny (1986) are satisfied which are present in table-6, there is a need to check the moderation role of cooperative norms between trust on leadership and knowledge sharing.

\section{(See Table-7 in APPENDIX)}

Results reported in table-7 confirm that all assumption of Barron and Kenny (1986) are proved. Results are showing that there is significant relationship exists between trust on leadership and knowledge sharing and equation is (KNS) 0.624(0.181), $\mathrm{t}=13.42, \beta=0.644, \mathrm{p}<0.000$. Assumption two stated that there should be significant relationship exists between independent variable (TOL) and moderator variable $(\mathrm{CN})$. Statistics in table-7 reveals that there is significant relation exists between both of them and equation is (TOL) 0.456(0.028) $t=4.435, \beta=0.568, p<0.000$. Assumption three for Barron and Kenny (1986) was that there should be a significant relationship exists between moderator variable $(\mathrm{CN})$ and dependent variable (KNS). Results presented in table-7 reveal that there is a significant relationship exists between these two variables, so the equation is $(\mathrm{CN}) 0.626(0.034), \mathrm{t}=3.445, \beta=0.465, \mathrm{p}<0.000$. Step-4 is checked by multiplying the independent variable (TOL) with moderator variable $(\mathrm{CN})$ and test the combine effect of these two on dependent variable (KNS). Equation for this step is $(\mathrm{TOL})(\mathrm{CN}) 0.456(0.028), \mathrm{t}=4.435, \beta=0.568, \mathrm{p}<0.000$. Adjusted $\mathrm{R}^{2}$ is raised from 0.414 to 0.415 which is very nominal, whereas $F=44.63, p<0.05$. Hence hypothesis -3 , cooperative norms moderate the interaction of trust on leadership and knowledge sharing, is accepted.

\subsection{Testing of Hypothesis-4}

\section{(See Table-8 in APPENDIX)}

In table-8 it has been observed that all assumptions for Barron and Kenny (1986) are satisfied. The variable (HRDM) has significant association with dependent variable (trust on leadership) and the equation of this relationship is (HRDM) 0.598(0.045), $\mathrm{t}$ $=13.25, B=0.639, \mathrm{p}<0.000$. The second assumption is connecting the independent variable $(\mathrm{HRDM})$ with moderator variable $(\mathrm{CN})$. The association between these two are seen as $(\mathrm{CN}) 0.498(0.07), \mathrm{t}=3.245, \beta=0.732, \mathrm{P}<0.000$. Moderating effect of $(\mathrm{CN})$ with $(\mathrm{HRDM})$ is explained as $(\mathrm{HRDM})(\mathrm{CN}) 0.669(0.052), \quad \mathrm{t}=13.25, \beta=$ $0.639, \mathrm{p}<0.05$. Value of $\mathrm{R}^{2}$ before moderation was 0.406 and after moderation analysis 
it became 0.430 which shows a significant variation in $\mathrm{R}^{2}$. These results significantly prove hypothesis- 4 which is cooperative norms moderate the relationship of human resource diversity management and knowledge sharing.

\section{CONCLUSION}

The data results describe that there is a significance relationship between HRDM and knowledge sharing. This study explored the effect of HR diversity management practices on employee knowledge sharing. Study also includes different fundamental, social and psychological procedures for measuring effect on knowledge sharing. The findings of current study are:

HR diversity management is positively associated with employee knowledge sharing. Firstly, when there is trust in leader was not included still HRDM significantly affecting employee knowledge sharing. There was also seen that HRDM practices vary from different firms.

Employee knowledge sharing behavior is also influenced by Trust on leadership. When Trust on leadership was included as a mediator between HRDM and Employee knowledge sharing there is significance mediation found.

Cooperative norms were included as moderator. The results has shown that there is significance moderation exist between trust on leadership and employee knowledge sharing. Since there is more knowledge sharing when cooperative norms will be high and there will be less knowledge sharing when cooperative norms will be low within the organization.

Cooperative norms also have a moderation effect between HRDM and trust on leadership. Since high cooperative norms will produce more trust and low cooperative norms will show low trust level on leadership.

These findings provide significant evidence that HRDM and knowledge sharing has positive, direct relationship and if we include different variable to explore, we will observe that different social and psychological processes effect knowledge sharing behavior.

\subsection{Academic and Managerial Implications of the study}

\subsubsection{Academic Implications}

This study finding provides a significant support to pervious literature which focuses on general effect of HR diversity management on employee knowledge sharing (Collins \& Smith, 2006), effect of HR diversity management on employee working and attitudes (Shen et al., 2014), multilevel analysis of HR diversity management on employee knowledge sharing (Shen et al., 2013), effect of HR diversity management on organization citizenship behavior. Findings of the study are also in compliance with 
the past studies in which researchers argued that HR has a vital role in diversity management (Kossek et al., 2005).

\subsubsection{Practical Implications}

Due to increase in globalization, diversity has also increased and now it has a prominent effect on today's business environment. Business now-a-days is facing more pressure from diversity related issue. Better and effective management of diversity is unavoidable for survival in this intensive competitive era. Effective diversity related issue is essential. This study provides a tested framework that how HRDM, trust on leadership, cooperative norms have a significant effect on employee knowledge sharing. For learning and innovation this frame work is very helpful.

\subsection{Limitations \& Future Research}

This study has potential limitations which are:

$\S$ Organizations which are situated only in Islamabad are considered in this study. Responses from one city are not enough for generalizability of the results.

$\S$ There are many other control variables which are not included in this study. For example, in context of Pakistan language and ethnic background could be taken as control variable. Future researches could address this concern.

$\S$ Limitations of this research lead towards future research:

$\S$ Since this study has not explored all dimensions of trust and knowledge sharing, such as trust on colleagues, trust on system (Whitener, 1997) etc. These factors can be considered as predictors of trust and knowledge sharing. So there is need to develop more extensive model by using all predictor of employee knowledge sharing.

$\S$ Finally this research study is focusing on culture and context of Pakistan, where diversity dimensions are different from other countries (for example UK-USA etc. has an issue of racial diversity). As a result of this limitation, the findings of the study could not be generalized, future studies could be attempted to collect data from other countries for getting more generalizable results. Cross cultural studies would be more helpful for getting different results.

\section{REFERENCES}

Adams, G. L., \& Lamont, B. T. (2003). Knowledge management systems and developing sustainable competitive advantage. $\hat{E} J o u r n a l ~ o f ~ k n o w l e d g e ~ m a n a g e m e n t, \hat{E} 7(2), 142-$ 154.

Alavi, M., \& Leidner, D. E. (2001). Review: knowledge management and 
knowledge management systems: conceptual foundations and research issues. ÊMIS quarterly, 107-136.

Allen, D. G., Shore, L. M., \& Griffeth, R. W. (2003). The role of perceived organizational support and supportive human resource practices in the turnover process, Journal of Management, 29(1), 99-118.

Amato, A., \& Zijlstra, F. R. H. (2008). Psychological climate and individual factors as antecedents of work outcomes, European Journal of Work and Organizational Psychology, 17(1), 33-54.

Anand, S., Vidyarthi, P. R., Liden, R. C., \& Rousseau, D. M. (2010). Good citizens in poor-quality relationships, idiosyncratic deals as a substitute for relationship quality, Academy of Management Journal, 53(5), 970-988.

Anderson, L., \& Person, C. (1999). Tit for Tat: The spiralling effect of incivility in t workplace, Academy of Management Review, 24(4), 452-471.

Baron, R. M., \& Kenny, D. A. (1986). The moderator-mediator variable distinction in social psychological research: conceptual strategic and statistical considerations, Journal of Personality and Social Psychology, 51(6), 1173-1182.

Beauregard, M., \& Paquette, V. (2008). EEG activity in Carmelite nuns during a mystical experience. Neuroscience Letters, 444(1), 1-4.

Bock, G. W. \& Kim, Y. G. (2002). Breaking the myths of rewards: an exploratory study of attitudes about knowledge sharing, Information Resources Management Journal, 15 (2), 14-21.

Bock, G. W., Zmud, R. W., Kim, Y. G., \& Lee, J. N. (2005). Behavioral intention formation in knowledge sharing: examining the roles of extrinsic motivators, socialpsychological forces, and organizational climate, MIS Quarterly, 29(1), 87-111.

Boon, S. D., \& Miller, R. J. (1999). Exploring the links between interpersonal trust and the reasons underlying gay and bisexual males' disclosure of their sexual orientation to their mothers.ÊJournal of homosexuality,Ê37(3), 45-68.

Carrell, M. R., Mann, E. E., \& Sigler, T. H. (2006). Defining workforce diversity programs and practices in organizations: A longitudinal study. Labor Law Journal, 57(1), 5-12.

Chan, K. W., \& Li, Z. (1999). The hukou system and rural-urban migration in China: processes and changes, the China Quarterly, 160, 818-855.

Cook, J., \& Wall, T. (1980). New work attitude measures of trust, organizational commitment and personal need non-fulfilment. ÊJournal of occupational 
psychology, $\hat{\mathrm{E}} 53(1), 39-52$.

Collins, C. J., \& Smith, K. G. (2006). Knowledge exchange and combination: The role of human resource practices in the performance of high-technology firms.ÊAcademy of management journal, 49(3), 544-560.

David, G. (2012). Testing Statistical Assumptions. Statistical Associates Publishing. Pp16.

Datta, D. K., Guthrie, J. P., \&Wright, P. M. (2005). HRM and labor productivity: does industry matter? Academy of Management Journal, 48, 135-145.

Dirks, K. T., \& Ferrin, D. L. (2002).Trust in leadership: meta-analytic findings and implications for research and practice, Journal of Applied Psychology, 8(47), 611-628.

D’Netto, B., \& Sohal, A. S. (1999). Human resource practices and workforce diversity: an empirical assessment, International Journal of Manpower, 20(8), 530-547.

Ehrhart, M. G., \& Naumann, S. E. (2004). Organizational citizenship behavior in work groups: a group norms approach, Journal of Applied Psychology, 89(6), 960-974.

Fishbein, M., \& Ajzen, I. (1975). Belief, attitude, intention, and behavior: an introduction to theory and research, reading, MA: Addison-Wesley.

Forsyth, D. (1999). Group Dynamics Pacific Grove, CA: Ed (3) Brook/Cole Publishing.

George, J. M., \& Jones, G. H. (1997). Experiencing work: values, attitudes, and moods, Human Relations, 50(4), 393-416.

Hardin, R. (2002). Trust and Trustworthiness, New York: Russell Sage Foundation 2.

Ipe, M. (2003). Knowledge sharing in organizations: a conceptual framework, Human Resource Development Review, 2(4), 337-359.

Kossek, E. E., Lobel, S. A., \& Brown, J. (2005). Michigan State University, Seattle University, WK Kellogg Foundation.

Kochan, T. A. (2003). The effects of diversity on business performance: report of the diversity research network, Human Resource Management, 42(1), 3-21.

Kreitz, P. A. (2009). Leadership and emotional intelligence: A study of university library directors and their senior management teams. College \& Research Libraries, 70(6), 531-554.

Lado, A. A., \& Wilson, M. C. (1994). Human resource systems and sustained competitive 
advantage: A competency-based perspective. ÊAcademy of management review,19(4), 699-727.

Lin, H. (2008). The modified Mahalanobis discriminant for predicting outer membrane proteins by using Chou's pseudo amino acid composition.ÊEJournal of Theoretical Biology,252(2), 350-356.

Martins, N. (2002). A model for managing trust.ÊInternational Journal of Manpower,23(8), 754-769.

Marques, J. F. (2008). Spiritual performance from an organizational perspective: the Starbucks way. Corporate governance, 8(3), 248-257.

Mayer, R. C., Davis, J. H., \& Schoorman, F. D. (1995). An integrative model of organizational trust, Academy of Management Review, 20(3), 709-734.

Mossholder, K. W., Richardson, H. A., \& Settoon, R. P. (2011). Human resource management systems and helping in organizations: a relational perspective, Academy of Management Review, 36(1), 33-52.

Olson, M. (1965). The Logic of Collective Action: Public Goods and the Theory of Groups, Cambridge, MA: Harvard University Press.

Pitts, D., and Jarry, E. (2009). Getting to know you: ethnic diversity, time and performance in public organizations, Public Administration, 87(3), 503-518.

Podsakoff, P. M., MacKenzie, S. B., Lee, J. Y., \& Podsakoff, N. P. (2003). Common method biases in behavioral research: a critical review of the literature and recommended remedies, Journal of Applied Psychology, 88(5), 879-903.

Reskin, B. F., \& McBrier, D. B. (2000). Why not ascription? Organizations' employment of male and female managers. $\hat{E} A$ merican sociological review, $\hat{E} 65(2), 210-233$.

Robinson, H. S., Carrillo, P. M., Anumba, C. J., \& Al-Ghassani, A. M. (2005). Knowledge management practices in large construction organisations. Engineering, Construction and Architectural Management, 12(5), 431-445.

Roberson, L., Kulik, C. T., \& Pepper, M. B. (2003). Using needs assessment to resolve controversies in diversity training design. Group \& Organization Management, 28(1), 148-174.

Rynes, S., \& Rosen, B. (1995). A field survey of factors affecting the adoption and perceived success of diversity training, Personnel Psychology, 48(2), 247-270.

Shen, J., Chanda, A., D'Netto, B., \& Monga, M. (2009). Managing diversity through human resource management: an international perspective and conceptual 
framework.ÊThe International Journal of Human Resource Management,Ê20(2), 235251.

Shen, J., Tang, N., \& D'Netto, B. (2013). A multilevel analysis of the effects of HR diversity management on employee knowledge sharing: the case of Chinese employees.ÊThe International Journal of Human Resource Management, 1-19.

Shen, J., D'Netto, B., \& Tang, J. (2014). Effects of HR Diversity Management on OCB in China, International Journal of Human Resource Management, 21(12), 2152-2168.

Van Dyne, L., Cummings, L. L., \& McLean, P. J. (1995). Extra-role behaviors: in pursuit of construct and definitional clarity (a bridge over muddied waters), Research in Organizational Behavior, 17, 215-285.

Waiganjo, M. E. W., Mukulu, E., \& Kahiri, J. (2012). Relationship between strategic human resource management and firm performance of Kenya's corporate organizations. International Journal of Humanities and Social Science, 2(10).

Whitener, E. M. (1997).The impact of human resource activities on employee trust, Human Resource Management Review, 7(4), 389-404.

Wilson, E. M., \& Iles, P. A. (1999). Managing diversity-an employment and service delivery challenge. International Journal of Public Sector Management, 12(1), 2749.

\section{APPENDIX}

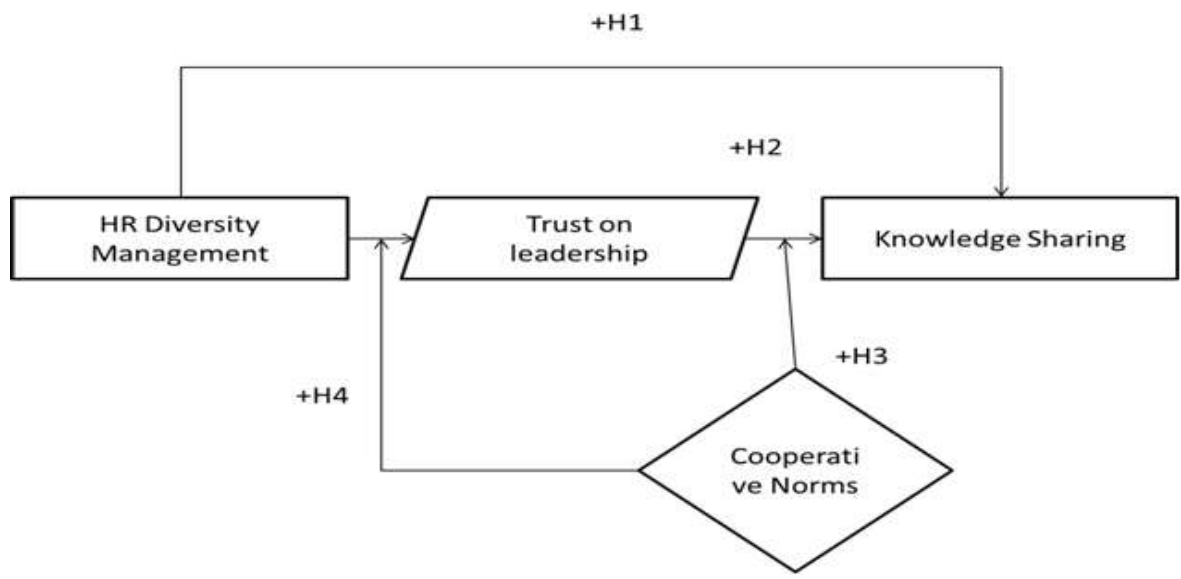

Figure 1: Theoretical Framework Showing Relation among Variables 
Table -1 Demographics $(\mathrm{N}=256)$

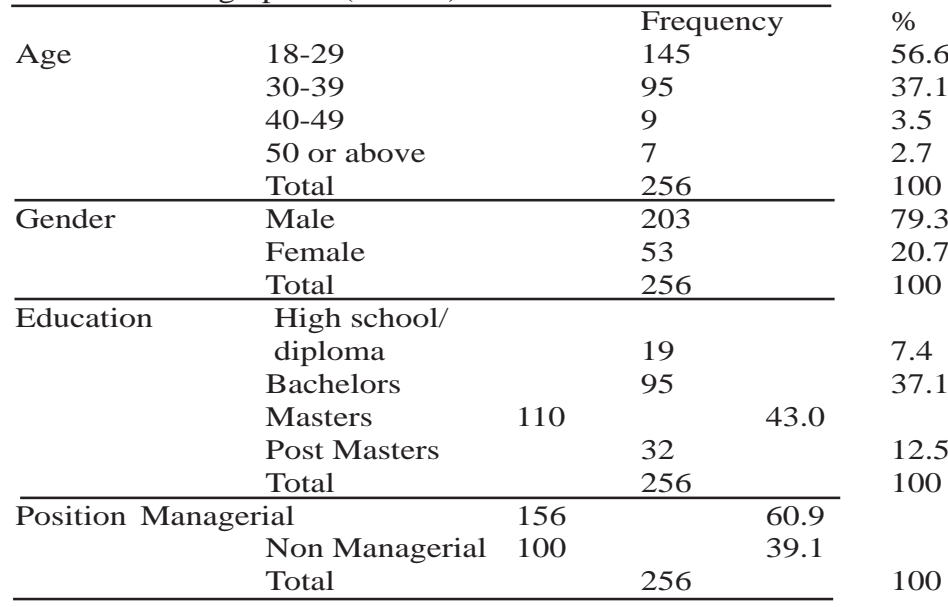

\begin{tabular}{lll}
\hline Variables & Cronbach's a & N of Items \\
\hline HRDM & 0.916 & 13 \\
KNS & 0.881 & 12 \\
TOL & 0.816 & 6 \\
CN & 0.799 & 5 \\
\hline
\end{tabular}

Table-3 Descriptive Statistics $(\mathrm{N}=256)$

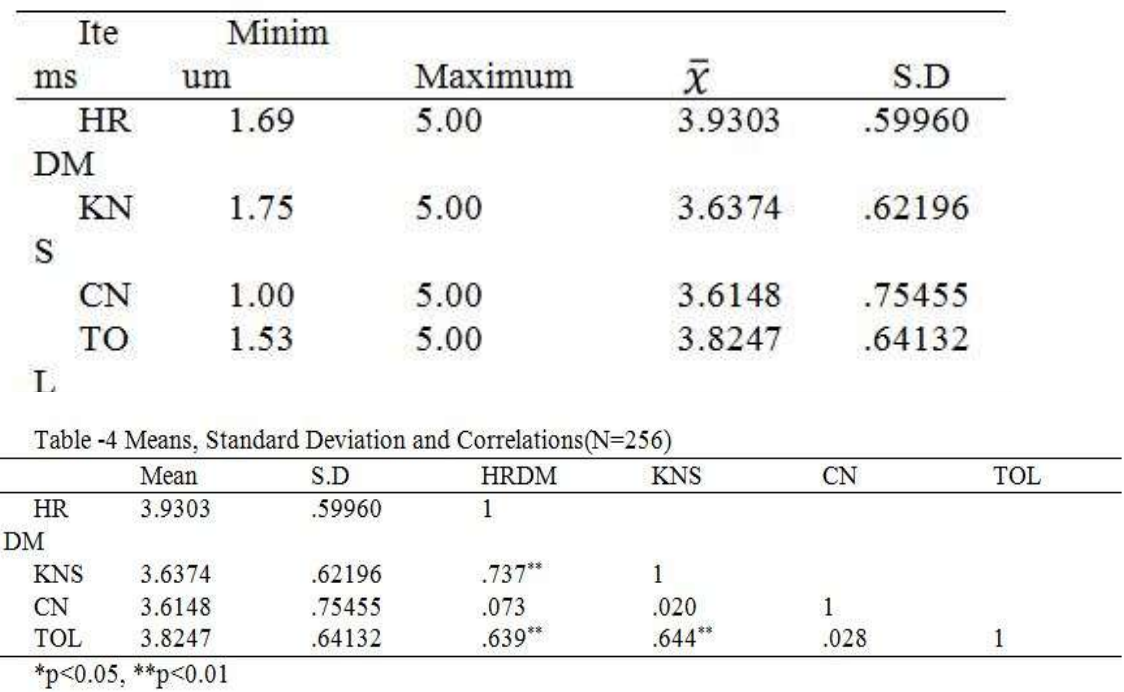

Table-5 Linear Regression Analysis (N=256)

\begin{tabular}{|c|c|c|c|c|}
\hline \multicolumn{3}{|c|}{$\begin{array}{l}\text { Unstandardized } \\
\text { Coefficients }\end{array}$} & \multirow{2}{*}{$T$} & \multirow{2}{*}{$\begin{array}{l}\text { Standardized Coefficients } \\
\beta\end{array}$} \\
\hline Variable & $B$ & Std. Error & & \\
\hline HRDM & 0.765 & 0.044 & 17.389 & $0.737^{*}$ \\
\hline (Constant) & .632 & .175 & 3.615 & \\
\hline
\end{tabular}


Table-6 Mediation analysis using Barron and Kenny (1986) (N=256) Variable

\begin{tabular}{|c|c|c|c|c|c|c|c|}
\hline Variable & $R^{2}$ & $\begin{array}{l}\text { Adjust } \\
e d R^{2}\end{array}$ & $F$ & $B$ & $B^{S E}$ & $T$ & $\beta$ \\
\hline \multirow{2}{*}{ Step 1: HRDM (IV) $\rightarrow$ KNS(DV) } & 0. & \multirow{2}{*}{0.542} & 302.3 & 0 . & 0. & 17.3 & 0.73 \\
\hline & 543 & & 68 & 765 & 044 & 89 & 7* \\
\hline \multirow{2}{*}{ Step 2: HRDM (IV) $\rightarrow$ TOL(MV) } & 0. & \multirow{2}{*}{0.406} & 175.4 & 0. & 0. & 13.2 & 0.63 \\
\hline & 409 & & 66 & 684 & 052 & 46 & $9^{*}$ \\
\hline \multirow{2}{*}{ Step 3: TOL (MV) $\rightarrow$ KNS (DV) } & 0. & \multirow{2}{*}{0.412} & 179.7 & 0. & 0. & 13.4 & 0.64 \\
\hline & 414 & & 79 & 624 & 047 & 08 & $4^{*}$ \\
\hline Mediation & & & & & & & \\
\hline H1 & 0. & 0.591 & 184.9 & 0 . & 0 . & 10.5 & 0.55 \\
\hline HRDM (IV) & 594 & 0.591 & 35 & 571 & 054 & 7 & 1 \\
\hline KNS (DV) $\zeta$ & & & & & & & \\
\hline TOL (MV) & & & & $\begin{array}{r}0 . \\
283\end{array}$ & $\begin{array}{r}0 . \\
051\end{array}$ & 5.6 & $2^{0.29}$ \\
\hline
\end{tabular}

Table -7 MODERATION analysis using Barron and Kenny (1986) (N=256)

\begin{tabular}{|c|c|c|c|c|c|c|c|}
\hline Variable & $R^{2}$ & $\begin{array}{r}\text { Adju } \\
\text { sted } R^{2}\end{array}$ & $F$ & $B$ & $B^{S E}$ & $T$ & $\beta$ \\
\hline \multirow{2}{*}{ Step 1: TOL (IV) $\rightarrow$ KNS (DV) } & 0. & \multirow{2}{*}{0.412} & 179 & 0. & 0. & 13. & 0.64 \\
\hline & 414 & & .78 & 624 & 181 & 41 & $4^{*}$ \\
\hline \multirow{2}{*}{ Step 2: TOL (IV) $\rightarrow \mathrm{CN}(\mathrm{MV})$} & 0. & \multirow{2}{*}{0.332} & 124 & 0. & 0. & 4.4 & 0.56 \\
\hline & 33 & & .65 & 456 & 028 & 35 & $8^{*}$ \\
\hline \multirow{2}{*}{ Step 3: CN (MV) $\rightarrow \mathrm{KNS}(\mathrm{DV})$} & 0. & \multirow{2}{*}{0.314} & 136 & 0. & 0. & 3.4 & 0.46 \\
\hline & 313 & & .65 & 626 & 034 & 45 & $5^{*}$ \\
\hline \multicolumn{8}{|l|}{ MODERATION } \\
\hline Step 4: TOL(IV)* ${ }^{*} \mathrm{~N}(\mathrm{MV}) \rightarrow \mathrm{KN}$ & 0. & & 44. & 0. & 0. & 6.6 & 0.38 \\
\hline (DV) & 415 & 0.413 & 628 & 066 & 01 & 8 & $7^{*}$ \\
\hline
\end{tabular}

Table -8 Moderation Analysis using Barron and Kenny (1986) $(\mathrm{N}=256)$ Variable

\begin{tabular}{|c|c|c|c|c|c|c|c|}
\hline Variable & $R^{2}$ & $\begin{array}{l}\text { Adjus } \\
\text { ted } R^{2}\end{array}$ & $F$ & $B$ & ${ }_{B} S E$ & $T$ & $\beta$ \\
\hline & 0. & & 175 & 0. & 0.0 & 13 & 0.639 \\
\hline Step 1: HRDM (IV) $\rightarrow$ TOL (DV) & 409 & 0.406 & .47 & 598 & 45 & .25 & * \\
\hline Step 2: HRDM (IV) $\rightarrow C N(M V)$ & $\begin{array}{r}0 . \\
321\end{array}$ & 0.331 & $.58^{125}$ & $\begin{array}{r}0 . \\
498\end{array}$ & $7^{0.0}$ & $\begin{array}{c}3 . \\
245\end{array}$ & * 0.732 \\
\hline Step $3: \mathrm{CN}(\mathrm{MV}) \rightarrow \mathrm{TOL}(\mathrm{DV})$ & $33^{0 .}$ & 0.332 & $.65^{124}$ & $\begin{array}{r}0 . \\
456\end{array}$ & $28^{0.0}$ & $\begin{array}{r}4 . \\
435\end{array}$ & * 0.568 \\
\hline $\begin{array}{l}\text { MODERATION } \\
\text { Step 4: HRDM(IV)*CN }(\mathrm{MV}) \rightarrow \\
\text { TOL (DV) }\end{array}$ & $\begin{array}{r}0 . \\
429 \\
\end{array}$ & 0.43 & $.47^{175}$ & $\begin{array}{r}0 . \\
669 \\
\end{array}$ & $52^{0.0}$ & $.25^{13}$ & $\begin{array}{r}0.6 \\
39 * \\
\end{array}$ \\
\hline
\end{tabular}

$\mathrm{P}<0.05$ 